\title{
KEBIJAKAN KREDIT USAHA RAKYAT (KUR) DALAM PANDANGAN THEORY OF JUSTICE JOHN RAWLS
}

\author{
Wadyo Pandapotan Pasaribu \\ Mahasiswa Program Pascasarjana STF Driyarkara
}

\begin{abstract}
This article with a title "The Policy of People Business Credit (PBC - ID: KUR) in the view of John Rawls' Theory of Justice" will firstly explain the economic condition of our country (the Republic of Indonesia) from the analysis of experts in economy and government's view to the current economic situation. Next, the discussion is about the formula of the policy of people business credit as an economic policy of Indonesian government in her effort to reduce the number of economic gap or income gap with a business fund allocation to SME through PBC program. Then, this article explains John Rawls' general principle of justice which is related to pareto optimality whereas on its practical level it is distributive justice that takes effect, in which each actor will get in accordance with his contribution in the market.
\end{abstract}

KEYWORDS: people business credit, distributive justice, John Rawls

ABSTRAK: Artikel yang berjudul "Kebijakan Kredit Usaha Rakyat (KUR) dalam Pandangan Theory of Justice John Rawls" ini pertama-tama akan memaparkan kondisi perekonomian negara kita (Republik Indonesia) dalam analisis pakar-pakar ekonomi dan pandangan pemerintah terhadap situasi ekonomi yang sedang berjalan. Selanjutnya akan diuraikan rumusan kebijakan kredit usaha rakyat sebagai kebijakan ekonomi pemerintah Indonesia dalam upaya mengurangi angka ketimpangan ekonomi atau ketimpangan pendapatan dengan pemberian dana usaha kepada UMKM melalui program KUR. Kemudian dipaparkan prinsip umum keadilan John Rawls terkait pareto optimality 
yang ketika di tingkat praksisnya berlaku keadilan distributif di mana masing-masing aktor akan memperoleh sesuai dengan kontribusinya dalam pasar.

KEYWORDS: kredit usaha rakyat, keadilan distributif, John Rawls

\section{Pendahuluan}

Kebijakan ekonomi pemerintah Indonesia terkait dengan Kredit Usaha Rakyat (KUR) patut diapresiasi, karena itu merupakan usaha pemerintah untuk menurunkan ketimpangan sosial yang terjadi hingga saat ini. Pemberian kredit berarti pemberian kemampuan usaha untuk rakyat supaya dapat meningkatkan kesejahteraannya. Tapi persoalannya, apakah kebijakan KUR efektif untuk mengatasi kesenjangan sosial yang masih menjadi problematika bangsa Indonesia? Tulisan ini akan mengevaluasi rumusan kebijakan KUR dari sudut pandang teori keadilan John Rawls. Meskipun karya John Rawls tentang teori keadilan telah diterbitkan pada abad lampau, namun teori ini Masih populer hingga saat ini. Karena keunikan dan kedalaman pemikirannya, karyakarya Rawls terlihat berbeda apabila dibandingkan dengan para filsuf kontemporer lainnya, sampai saat ini kontribusi pemikirannya terus diperbincangkan tidak hanya di ranah filsafat namun lintas disiplin ilmu. Theory of Justice (TOJ), karya Rawls yang menjadi referensi dalam tulisan ini dalam bahasa Indonesia diterjemahkan menjadi Teori Keadilan John Rawls, telah diterbitkan dalam versi bahasa Indonesia, dan masih mudah dijumpai di toko-toko buku. Itu berarti sudut pandang teori keadilan John Rawls layak untuk mengevaluasi kebijakan ekonomi pemerintah Indonesia terkait KUR.

Kesejahteraan Sosial Rakyat Indonesia

Tantangan yang cukup berat menghinggapi perekonomian Indonesia saat ini adalah kualitas pertumbuhan ekonominya yang tidak terlalu baik. Pertumbuhan ekonomi dianggap berkualitas apabila perekonomian tidak terlalu banyak dihinggapi tiga persoalan besar: 
ketimpangan, kemiskinan dan pengangguran. Pada triwulan III, data INDEF (Institute for Development of Economics and Finance) menunjukkan, tahun 2016 perekonomian mencatat pertumbuhan sebesar 5.02 persen (termasuk pertumbuhan yang tertinggi di dunia berdasar data World Economic Outlook Database IMF, 2016), namun di sisi lain terjadi ketimpangan pendapatan yang masih besar, dengan indeks gini ratio (indeks ketimpangan ekonomi) 0.40, angka kemiskinan 10.7 persen atau setara dengan 28 juta orang, dan pengangguran 5,6 persen. Secara sederhana situasi tersebut mendeskripsikan ketimpangan ekonomi dalam masyarakat dan nilai beli mayoritas masyarakat lemah sehingga secara cause-effect menyebabkan produktivitas menurun. Hal ini akan bermuara pada masalah-masalah sosial.

Dalam suatu riset Tadjoedin (2001) mengatakan, ketimpangan ekonomi yang terjadi dalam waktu yang berlarut-larut atau kesenjangan ekonomi yang berlarut-larut dapat memberikan dampak yang tidak sehat dalam bernegera, bahkan lebih jauh dapat menjadi suatu pemicu keresahan sosial yang bisa berujung revolusi sosial (contoh: konflik SARA 1960 di Malaysia dan 1998 di Indonesia). Angka gini ratio pendapatan yang menunjukkan angka mendekati 0,5 persen telah menjadikan sulitnya mayoritas masyarakat dalam memenuhi kebutuhannya, sekaligus ini menjadi alarm untuk mengantisipasi terjadinya keresahan sosial seperti yang disampaikan riset Tadjoedin.

Mewujudkan kesejahteraan sosial bagi seluruh rakyat Indonesia, adalah salah satu cita-cita utama Negara Kesatuan Republik Indonesia (NKRI). Dalam Pembukaan UUD 1945 telah dituliskan tujuan bernegara secara sangat luas, yakni (1) melindungi segenap bangsa dan seluruh tumpah darah Indonesia; (2) memajukan kesejahteraan umum; (3) mencerdaskan kehidupan bangsa; dan (4) ikut serta melaksanakan perdamaian dunia berdasarkan kemerdekaan; perdamaian abadi dan keadilan sosial. Prof Didin Damanhuri, seorang ekonom sekaligus pendiri INDEF (Institute for Development of Economics and Finance), dalam tulisannya yang terangkum dalam buku Menuju Ketangguhan Ekonomi: 
Sumbang Saran 100 Ekonom Indonesia, menuliskan interpretasinya terhadap tujuan bernegara tersebut sebagai berikut: Yang pertama bermakna geopolitik dan geoekonomi, yakni terjaminnya integritas politik dan ekonomi di wilayah Indonesia. Yang kedua bermakna "model pembangunan ekonomi" yang berorientasi kesejahteraan rakyat sebesarbesarnya (bukan semata kesejahteraan orang per orang). Yang ketiga bermakna kualitas kehidupan (bukan sekadar ekonomi, melainkan juga politik dan budaya) dari bangsa keseluruhan (bukan semata orang per orang) yang cerdas (baik inteligensia, emosional, maupun spiritual). Yang keempat bermakna bahwa dengan kapasitas 1, 2 dan 3 tersebut, harus teresonansi dalam kapasitas bangsa secara internasional yang mampu ikut serta dalam mewujudkan perdamain abadi. Dan keempat tujuan tersebut menurut Prof. Didin Damanhuri harus didasarkan pada prinsip keadilan sosial (baik di level nasional maupun global). ${ }^{1}$

Bila memperhatikan pendapat Didin terhadap poin kedua dari Pembukaan UUD 1945, memajukan kesejahteraan umum bermakna "model pembangunan ekonomi" yang berorientasi kesejahteraan rakyat sebesar-besarnya, bukan semata kesejahteraan orang per orang, membuat kita perlu melihat kembali situasi aktual kehidupan ekonomi masyarakat kita dan menelusuri kembali sistem ekonomi yang diterapkan di Indonesia, apakah dalam perjalanan bangsa ini tujuan negara memajukan kesejahteraan umum sudah tercapai atau paling tidak sudah menunjukkan situasi yang baik dalam sosial masyarakat.

Lincoln Asryad dalam tulisannya, "Pertumbuhan Ekonomi yang Berkualitas" menyitir data yang dirilis World Economic Outlook Database (IMF, 2016) tentang tingkat PDN negara-negara, mengatakan, jika dibandingkan dengan Malaysia dan Thailand, pertumbuhan ekonomi Indonesia pada tahun 2016 diperkirakan lebih tinggi ketimbang

1 Didin S. Damanhuri, "Ekonomi, Pertumbuhan Ekonomi, dan Tujuan Bernegara", dalam Menuju Ketangguhan Ekonomi Indonesia: Sumbang Saran 100 Ekonom Indonesia, ed. Tim INDEF (Jakarta: Penerbit Buku Kompas, 2017), 412-6. 
kedua negara tersebut. Ekonomi Indonesia diestimasi tumbuh setinggi 5 persen ${ }^{2}$, sementara kedua negara tersebut masing-masing hanya tumbuh 4,3 persen dan 3,2 persen, serta dalam kurun waktu hampir satu dekade terakhir, pertumbuhan ekonomi Indonesia relatif stabil di atas 5 persen per tahun dan termasuk tertinggi di dunia bersama China, Brasil dan India serta Afrika Selatan.

Namun ironisnya, di tengah pertumbuhan ekonomi yang relatif tinggi, tingkat kemiskinan masih mencapai 10,86 persen atau setara dengan 28 juta orang (Maret 2016, BPS) walaupun terjadi penurunan tetapi kecenderungannya lambat bahkan relatif stuck. Koefisien Gini ${ }^{3}$ sebagai standar yang digunakan untuk mengukur kesenjangan pendapatan dan kekayaan di Indonesia menunjukkan angka yang semakin meningkat dari waktu ke waktu. Data Badan Pusat Statistik (BPS) menunjukkan bahwa pada tahun 2003 sebesar 0,32 menjadi 0,36 pada 2007, menjadi 0,38 pada 2010, naik lagi menjadi 0,41 pada 2013, dan pada 2015 mencapai angka 0.43 .4

Dalam tulisannya, "Kesenjangan Sosial Ekonomi” Kwik Kian Gie mengatakan, mengacu pada formula Bank Dunia yang menetapkan ambang garis kemiskinan adalah pendapatan sebesar US \$ 2 per orang perhari, maka bila ukuran ini diterapkan pada Indonesia, artinya sebanyak 50 persen warga Indonesia tergolong miskin. ${ }^{5}$

2 Lincolin Arsyad, "Pertumbuhan Ekonomi yang Berkualitas", dalam Menuju Ketangguhan Ekonomi Indonesia: Sumbang Saran 100 Ekonom Indonesia, ed. Tim INDEF (Jakarta: Penerbit Buku Kompas, 2017), 455-7.

3 Agregat Koefisien gini (range 0 - 1) adalah ukuran statistik pertebaran paling menonjol, digunakan sebagai ukuran ketidakserataan distribusi pendapatan atau ketidakmerataan distribusi kekayaan. Semakin kecil nilainya, menunjukkan distribusi yang lebih merata. Demikian juga sebaliknya. Lih. https://www.dictio.id/t/apakah-yang-dimaksud-dengan-koefisiengini/8371/2. Diakses 16 April 2018.

4 Lincolin Arsyad, "Pertumbuhan Ekonomi yang Berkualitas", 455. Peningkatan koefisien gini berarti kondisi distribusi pendapatan secara perseorangan semakin pincang."

5 Kwik Kian Gie, "Kesenjangan Sosial Ekonomi", dalam Menuju Ketangguhan Ekonomi Indonesia: Sumbang Saran 100 Ekonom Indonesia, ed. Tim INDEF (Jakarta: Penerbit Buku Kompas, 2017), 450-3. 
Di sisi lain, dalam proporsi penguasaan aset di Indonesia, Bambang Widianto, dalam tulisannya "Tantangan Mengurangi Kemiskinan, Kerentanan dan Ketimpangan" mengatakan satu persen keluarga terkaya di Indonesia menguasai hampir 50 persen aset, sementara 10 persen keluarga terkaya menguasai 70 persen aset". Widianto dalam tulisan tersebut menampilkan data dari Credit Suisse Global Wealth Databooks, yang merilis data bahwa Indonesia termasuk 5 besar negara tertimpang di dunia dengan proporsi aset yang dikuasai oleh 1 persen orang kaya. ${ }^{6}$

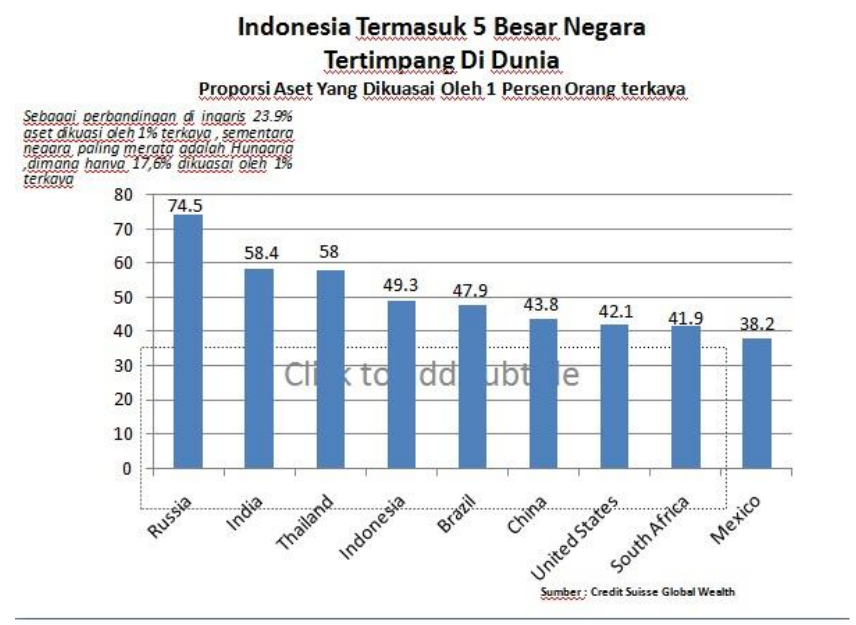

Dituliskannya sebagai perbandingan di Inggris 23,9 persen aset dikuasi 1 persen terkaya, sementara negara paling merata adalah Hungaria, di mana hanya 17,6 persen aset yang dikuasai oleh 1 persen terkaya.

Melihat uraian para ahli di atas dan penyajian data yang diberikan, maka tidak dapat ditolak Indonesia berada dalam problema keadilan sosial. Ketidakmerataan ekonomi sedang dan masih terjadi di dalam

6 Bambang Widianto, "Tantangan Mengurangi Kemiskinan, Kerentanan dan Ketimpangan", dalam Menuju Ketangguhan Ekonomi Indonesia: Sumbang Saran 100 Ekonom Indonesia, ed. Tim INDEF (Jakarta: Penerbit Buku Kompas, 2017), 394-8. Pada tulisan ini Dr. Widianto menambahkan, sebagai perbandingan di Inggris 23,9\% aset dikuasai $1 \%$ terkaya, sementara negara paling merata adalah Hungaria dimana hanya 17,6\% dikuasai oleh $1 \%$ terkaya." 
masyarakat. Meskipun pertumbuhan ekonomi nasional meningkat namun hal itu tidak berdampak signifikan terhadap peningkatan ekonomi masyarakat. Kembali kepada cita-cita NKRI yang tertuang dalam Pembukaan UUD 1945 yang salah satunya adalah menciptakan kesejahteraan sosial yang tentunya berkeadilan sosial masih belum terwujud.

\section{Misteri Ketimpangan Ekonomi di Tengah Pertumbuhan Ekonomi}

Wakil Menteri Keuangan RI, Mardiasmo, dalam sebuah acara diskusi ekonomi bersama 100 ekonom di Main Hall Bursa Efek Jakarta pada $4 / 4 / 2017^{7}$, mengatakan pertumbuhan ekonomi dan timpangnya angka kesenjangan adalah suatu ironi yang masih menjadi misteri yang harus selalu diupayakan solusinya di setiap pemerintahan.

Data BPS menunjukkan bahwa selama lima tahun terakhir ini, pangsa produk domestik bruto (PDB) yang dihasilkan di Pulau Jawa masih di atas 55 persen. Hal ini menunjukkan konsentrasi perekonomian masih sangat bertumpu di Pulau Jawa, dan menunjukkan distribusi pendapatan yang lebih berpusat di Pulau Jawa. Lincoln Arsyad, menyitir studi dari Sunandar (2005) menunjukkan adanya pembangunan ekonomi regional yang tidak seimbang di Indonesia, khususnya antara kawasan barat dan timur. Pembangunan cenderung terkonsentrasi di wilayah Sumatera, Jawa dan Bali yang menguasai lebih dari 80 persen pangsa PDB Nasional dan PDB per kapita wilayah barat dua kali lipat lebih tinggi daripada wilayah timur. ${ }^{8}$

Terjadinya ketimpangan ekonomi dan distribusi pendapatan yang tidak merata di tengah terjadinya peningkatan pertumbuhan ekonomi adalah suatu pekerjaan rumah tangga yang harus segera ditemukan

\footnotetext{
7 Wamenkeu Mardiasmo sebagai pembicara mewakili Menteri Keuangan Sri Mulyani, bersama Chairul Tanjung, Bustanil Arifin, Mirza Adityaswara, pada acara Launching Buku dan Diskusi bersama 100 Ekonom di Main Hall Bursa Efek Indonesia (BEI), 4/4/2017, diselenggarakan oleh INDEF (Institute for Development of Economics and Finance).

8 Lincolin Arsyad, "Pertumbuhan Ekonomi yang Berkualitas", 455-7.
} 
solusi yang tepat. Dan sebelum penentuan serum yang tepat untuk mengobati "penyakit" tersebut terlebih dahulu harus diketahui secara akurat apa penyebabnya. Prof Didin Damanhuri, menuliskan dalam penelitannya, ketimpangan ekonomi sering terjadi di negara-negara yang GDP-Oriented (berorientasi PDB), yakni negara yang secara overall mengukur kemajuan negaranya yang utama melalui PDB tersebut. Didin Damanhuri memberikan contoh, Amerika Serikat (AS) merupakan negara dengan tingkat kemakmuran yang tertinggi di dunia, namun kemiskinan masyarakat AS juga termasuk tinggi untuk ukuran negara maju, yakni 18 persen menurut ukuran statistik mereka. ${ }^{9}$

Pendapat ekstrim disampaikan oleh Kwik Kian Gie dalam tulisannya, Kesenjangan Sosial Ekonomi 2017, mengatakan penyebab kesenjangan ekonomi yang besar ketika pertumbuhan ekonomi besar terjadi pada sistem ekonomi yang liberal di mana keikutcampuran pemerintah dalam bidang produksi, distribusi dan konsumsi kecil sekali. Kwik Gian Gie menyitir pendapat Thomas Piketty ${ }^{10}$ dari karyanya Capitalism in the $21^{\text {st }}$ Century, bahwa return on capital lebih besar dibandingkan dengan Produk Domestik Bruto (PDB) di bagian-bagian dari dunia yang menganut liberalisme yang sejauh mungkin ${ }^{11}$. Kwik Kian Gie memberikan beberapa contoh kebijakan pemerintah yang menurutnya membuka peluang liberalisme berjalan sejauh mungkin.

Christianto Wibisono, seorang analis bisnis, dan pendiri Pusat Data Bisnis Indonesia (PDBI) menuliskan dalam “Seabad Indonesia 2045:

9 Didin S Damanhuri, "Ekonom, Pertumbuhan Ekonomi, dan Tujuan Bernegara", 415.

10 Thomas Piketty (Lahir 7 Mei 1971) adalah ekonom Perancis yang sering menulis karya tentang pendapatan dan ketimpangan kekayaan. Ia merupakan direktur studi di École des hautes études en sciences sociales (EHESS) dan dosen di Paris School of Economics. Ia adalah pengarang buku laris Capital in the Twenty-First Century (2013) yang berfokus pada pemusatan dan distribusi kekayaan selama 250 tahun terakhir. Buku tersebut berpendapat bahwa jika tingkat akumulasi modal naik lebih cepat ketimbang pertumbuhan ekonomi, ketimpangan ekonomi akan meningkat. Ia mengusulkan pajak kekayaan global untuk menyelesaikan masalah ketimpangan yang terjadi saat ini.

https://www.britannica.com/biography/Thomas-Piketty

11 Kwik Kian Gie, "Kesenjangan Sosial Ekonomi", 452. 
Menuju Peringkat Besar Dunia" Indonesia masih dipengaruhi atau masih mewarisi dampak dari rezim sebelumnya (Orde Lama dan Orde Baru) ${ }^{12}$ sambil berada dalam pusaran The Clash of Civilization ${ }^{13}$ yang melanda secara global. Dua situasi itu membuat banyak kesulitan dalam perbaikan kesejahteraan eknomi Indonesia. Namun menurut Christian Wibisono, hal-hal itu sekaligus menjadi ujian bagi pemerintah yang bila dapat dilalui akan membawa Indonesia lepas dari jebakan negara berpendapatan menengah (middle income trap) yang mengekang Indonesia untuk melesat maju. ${ }^{14}$

Hendri Saparani, Ekonom pendiri Center of Reform on Economic (CORE) menuliskan dalam "Mendorong Kualitas Konsumsi Rumah Tangga dan Pertumbuhan Ekonomi" kesenjangan yang lebar dalam pendapatan masyarakat serta keparahan angka kemisikinan disebabkan oleh konsumsi belanja rumah tangga menengah atas dan rumah tangga kelas bawah mengalami perbedaan yang sangat tinggi. Hendri Saparini mengawali analisisnya dengan menyampaikan pertumbuhan ekonomi Indonesia yang relatif stabil selama ini sangat bersandar pada pertumbuhan konsumsi swasta dengan kontribusi sekitar 55 persen terhadap produk domestik bruto (PDB).

Kemudian disampaikan bahwa pertumbuhan konsumsi swasta ternyata sangat ditopang oleh belanja dari rumah tangga menengah-

\footnotetext{
12 Christianto Wibisono, "Seabad Indonesia 2045: Menuju Peringkat 4 Besar Dunia", dalam Menuju Ketangguhan Ekonomi Indonesia: Sumbang Saran 100 Ekonom Indonesia, ed. Tim INDEF (Jakarta: Penerbit Buku Kompas, 2017), 124-7.

13 Benturan peradaban atau Clash of Civilizations $(\mathrm{CoC})$ adalah suatu grand theory Prof. Samuel Huntington. Teori bahwa identitas budaya dan agama seseorang akan menjadi sumber konflik utama di dunia pasca-Perang Dingin. Teori ini dipaparkan Samuel P. Huntington dalam pidatonya tahun 1992 di American Enterprise Institute, lalu dikembangkan dalam artikel Foreign Affairs tahun 1993 berjudul "The Clash of Civilizations?",sebagai tanggapan atas buku karya mahasiswanya, Francis Fukuyama, berjudul The End of History and the Last Man (1992). Huntington kemudian mengembangkan tesisnya dalam buku The Clash of Civilizations and the Remaking of World Order (1996).

14 Christianto Wibisono, "Seabad Indonesia 2045: Menuju Peringkat 4 Besar Dunia", 124.
} 
atas. ${ }^{15}$ Bagaimana posisi ini dapat menjadi masalah, menurut Hendri salah satunya adalah tekanan terhadap daya beli masyarakat bawah semakin sulit adalah ketika menghadapi tingkat inflasi yang berakibat daya produksi rumah tangga masyarakat bawah semakin rendah.

Banyak dimensi yang menyebabkan ketimpangan ekonomi di Indonesia, pengaruh eksternal maupun internal. Tetapi yang terbesar adalah problema internal seperti sistem ekonomi, penerapan kebijakan, strategi pemerataan struktur ekonomi, distrubusi income yang merata di setiap daerah dan hal-hal lain yang mungkin memiliki dampak signifikan. Hal yang terpenting dari situasi tersebut, selain menemukan penyebabnya, hal yang sama pentingnya adalah menciptakan solusi.

\section{Kebijakan Kredit Usaha Rakyat (KUR) bagi Usaha Mikro, Kecil dan Menengah (UMKM)}

Usaha Mikro, Kecil dan Menengah (UMKM) sebagai elemen signifikan dalam usaha mengurangi ketimpangan

Ketimpangan ekonomi yang melanda kehidupan masyarakat Indonesia, adalah suatu dilema yang tidak pernah berhenti di tengah kebutuhan masyarakat untuk melanjutkan kehidupan atau keinginan pemerintah untuk menciptakan pemerataan bahkan di tengah situasi global yang tidak menentu.

Para pakar sudah menguraikan dengan baik faktor-faktor apa saja yang paling signifikan penyebab terjadinya ketimpangan ekonomi tersebut. Seperti Didin S. Damanhuri, dalam tulisannya "Ekonom, Pertumbuhan dan Tujuan Bernegara" (2017) mengatakan, mindset ekonomi negara terjebak pada growth oriented atau berorientasi pada "ideologi pertumbuhan ekonomi" tetapi tidak berupaya maksimal dalam memecahkan problem kemiskinan. Hendri Saparani dalam "Mendorong

15 Hendri Saparini, "Mendorong Kualitas Konsumsi Rumah Tangga dan Pertumbuhan Ekonomi", dalam Menuju Ketangguhan Ekonomi Indonesia: Sumbang Saran 100 Ekonom Indonesia, ed. Tim INDEF (Jakarta: Penerbit Buku Kompas, 2017), 175-9. 
Kualitas Konsumsi Rumah Tangga dan Pertunbuhan Ekonomi (2017)" menuliskan, Pertumbuhan ekonomi kita sangat bersandar pada pertumbuhan konsumsi swasta yang mencapai 55 persen, sementara angka tersebut sangat ditopang oleh belanja dari rumah tangga menengah atas. Di lain sisi rumah tangga menengah bawah yang populasinya mendominasi, tumbuh sangat rendah (hanya kurang dari 3 persen). Kwik Kian Gie dalam "Kesenjangan Sosial Ekonomi (2017)" mengatakan, sistem ekonomi yang dijalankan secara operasional saat ini adalah bernuansa liberal, sehingga tidak punya keberpihakan yang serius pada kelompok ekonomi menengah bawah, seperti perhatian kepada UMKM yang mendominasi jumlah usaha di Indonesia yaitu 99,99 persen, dibanding usaha besar hanya 0,01 persen. Tetapi kontribusi UMKM dalam PDB hanya 60,34 persen sedangkan perusahaan raksasa yang 0,01 persen menyumbang 39,66 persen. Jossy Prananta Moeis dalam “Makna Hakiki Pembangunan untuk Kedaulatan Pangan (2017)" memberikan tanggapannya angka pemilikan lahan yang sangat mencemaskan, yaitu meningkat dari 0,64 di tahun 1993 menjadi 0,72 di tahun 2003 yang kemudian diperkirakan mencapai 0,8 pada 2013, artinya, terjadi ketimpangan luar biasa dan semakin parah, di mana petani tanpa lahan, dan berlahan sempit, semakin banyak. Bisa ditebak, keluarga tani di perdesaan Indonesia kesejahteraannya semakin menurun.

Analisis para pakar di atas memiliki paling tidak dua kesepakatan, yaitu perlunya keberpihakan yang lebih serius kepada pertumbuhan UMKM dan kelompok marginal dan perlunya menimbang ulang atau mengevaluasi kembali sistem ekonomi yang sedang dijalankan apakah porsi inklusivitasnya sudah dominan atau belum.

Presiden Joko Widodo, dalam pidatonya di hadapan para Peserta Kongres Ekonomi Umat (22/4/2017) mengatakan "meski pertumbuhan ekonomi Indonesia sekitar 5,2 persen dan pada tahun 2017 tertinggi di dunia setelah India dan China, tetapi siapa yang menikmatinya? Data- 
data ketimpangan kaya-miskin sangat mengkhawatirkan," kata Presiden ${ }^{16}$. Presiden Jokowi menyampaikan beberapa solusi yang harus dilakukan antara lain, mendistribusikan 12,5 juta hektar lahan kepada rakyat yang tidak memiliki lahan; memperbesar akses dana perbankan kepada UMKM dan sejumlah program lain untuk memperbaiki kondisi ketimpangan tersebut.

Kebijakan dengan memberi perhatian yang serius pada UMKM dengan memperbesar akses dana perbankan adalah pilihan yang tepat dalam pandangan para ekonom maupun pemerintah, sehingga disadari betapa posisi UMKM adalah salah satu sektor yang signifikan untuk mengurangi ketimpangan ekonomi. Selanjutnya kita akan melihat bagaimana kebijakan ini terwujud dengan terbentuknya program Kredit Usaha Rakyat.

\section{Pelaksanaan Program KUR}

Program KUR yang dijalankan dimulai sejak 2007 berfokus pada pembiayaan usaha mikro, kecil, dan menengah. Kategori pembiayaan dikelompokkan berdasarkan tiga skema yaitu, segmen mikro, segmen ritel dan segmen linkage (penempatan TKI). Segmen mikro mendapat maksimal plafon mencapai 25 juta, segmen ritel mencapai 500 juta dan segmen penempatan TKI plafon sampai dengan 25 juta per debitur ${ }^{17}$. Kebijakan itu dimulai sejak 2007 di masa pemerintahan Presiden Susilo Bambang Yudhoyono (SBY) dengan landasan hukumnya, Inpres No. 6 Tahun 2007 tentang Kebijakan Percepatan Pengembangan Sektor Riil dan UMKM.

Menurut Awalil Rizky, dalam tulisannya "Kredit Usaha Rakyat" (2017) Presiden Jokowi mengakui kesuksesan program KUR tersebut ${ }^{18}$.

\footnotetext{
16 Pidato Presiden Jokowi pada pembukaan Kongres Ekonomi Umat, bertema "Arus Baru Ekonomi Indonesia" yang dihadiri beberapa pejabat negara dan pengusaha nasional dan para ulama, di Jakarta, 22 April 2017.

17 www.kur.ekon.go.id. Diakses 20 Oktober 2017 dan 16 April 2018.

18 Awalil Rizky, "Kredit Usaha Rakyat Harus Dikaji Ulang", 303.
} 
Pertimbangan utama dilanjutkannya kebijakan pemberian modal kepada UMKM adalah sebagai upaya untuk mengurangi kesenjangan dan menumbuhkan produktivitas masyarakat menengah ke bawah.

Di era Pemerintahan Presiden Jokowi Program KUR didukung dengan dikeluarkannya Keputusan Presiden, Keppres No.14 Tahun 2015 tentang Komite Kebijakan Pembiayaan bagi Usaha Mikro, Kecil, Dan Menengah yang kemudian diperbaharui dengan Keppres No 19 tahun 2015 Perubahan atas Keputusan Presiden Nomor 14 Tahun 2015 tentang Komite Kebijakan Pembiayaan Bagi Usaha Mikro, Kecil, dan Menengah. Hal itupun diikuti dengan penggandaan skala dana subisidi untuk KUR tersebut. ${ }^{19}$

Bila membandingkan kebijakan pelaksanaan KUR di era SBY dan Jokowi yang mencolok adalah pada pemberian bunga kredit. Pemerintah Jokowi menurunkan bunga kredit dari semula 22 persen untuk Kredit Mikro dan 12 persen ritel di era SBY, menjadi 12 persen yang kemudian diturunkan kembali menjadi 9 persen per tahun untuk kredit mikro dan ritel, serta 13 persen untuk Kredit Penempatan TKI ${ }^{20}$. Wakil Presiden Jusuf Kalla, dalam suatu pidato mengatakan penurunan bunga KUR adalah upaya konkret pemerintahan Jokowi untuk mengurangi kesenjangan antara pengusaha besar dan kecil, di mana di masa sebelumnya pemberian bunga KUR dikatakan lebih menguntungkan pengusaha besar dan menyulitkan pengusaha kecil, sehingga banyak pengusaha kecil tidak dapat tumbuh malah gulung tikar. ${ }^{21}$

Penyaluran dana KUR sejak pemerintahan Jokowi menetapkan target spektakuler, selain dana subsidi yang semakin tinggi sehingga

\footnotetext{
19 Ibid.

20 Awalil Rizky, "Kredit Usaha Rakyat Harus Dikaji Ulang", dalam Menuju Ketangguhan Ekonomi Indonesia: Sumbang Saran 100 Ekonom Indonesia (Jakarta: Penerbit Buku Kompas, 2017), hlm. 303 “dengan menurunkan bunga kredit kepada nasabah yaitu maks. 9\%, maka kepada bank penyalur diberikan subsidi untuk kur mikro sebesar 10 persen, kur ritel sebesar 4,5 persen dan kur tenaga kerja Indonesia sebesar 12 persen."

21 http://nasional.kompas.com/read/2017/01/24/20190411/wapres.sindir.kebijakan.kredit. usaha.rakyat.era.sby. Diakses 21 April 2017 dan 16 April 2018.
} 
bunga kredi rendah, Anggaran Pendapatan dan Belanja Negara (APBN) 2016, menetapkan target penyaluran KUR sebesar Rp 100 triliun. Terjadi peningkatan signifikan penyaluran KUR sejak 2015/2016.

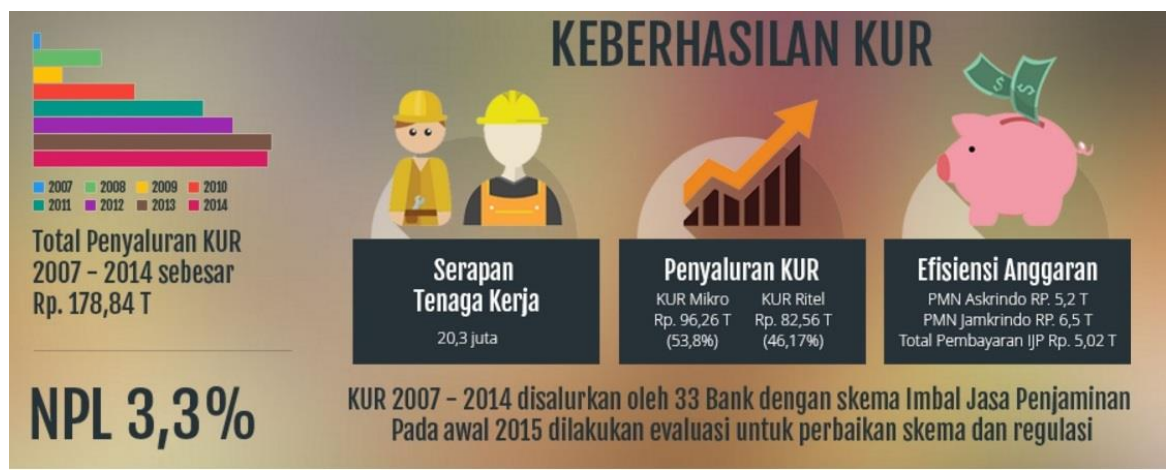

Realisasi penyaluran KUR 2007-2014. Sumber: www.kur.ekon.go.id

Perundangan dan Peraturan yang mendasari Kredit Usaha Rakyat sebagai pendanaan untuk Usaha Mikro Kecil dan Menengah (UMKM)

Dalam Bab awal buku Theory of Justice (ToJ) atau Teori Keadilan, Rawls menuliskan:

The point to keep in mind is that a conception of justice for the basic structure is worth having for its own sake. It should not be dismissed because its principles are not everywhere satisfactory. ${ }^{22}$

"Poin yang perlu diingat adalah bahwa konsep keadilan bagi struktur dasar sangatlah berharga untuk dimiliki. Hal ini tidak boleh dihapus karena prinsip-prinsipnya tidak selalu memuaskan di semua tempat".

Konteks pembicaraan Rawls dalam kutipan tersebut adalah pada Bab Keadilan sebagai fairness dengan topik pembicaraan subjek keadilan. Rawls ingin menyampaikan bahwa betapa pentingnya untuk terlebih dahulu mengenali, memiliki atau menyepakati suatu konsep keadilan sebelum menyusun suatu aturan dengan prinsip-prinsip keadilan. Bagi

22 John Rawls, A Theory of Justice (Revised) (Cambridge, Mass: Belknap Press, 1990), 8. 
Rawls konsep keadilan yang mendahuli prinsip keadilan akan memberikan sebuah standar bagaimana aspek-aspek dasar struktur masyarakat mesti diukur. Dalam bahasa yang lebih sederhana Rawls ingin mengatakan tidak selalu menjadi utama bagaimana masalahmasalah keadilan dipecahkan, melainkan mampu memilih prinsipprinsip mana yang harus didasari pada perundangan.

Berhubung dengan itu, maka kita perlu melakukan suatu analisis bertahap, yaitu melihat produk-produk hukum berdirinya KUR sebagai pendanaan untuk UMKM kelengkapan perangkat-perangkat "konstitusi" tersebut dianalisis untuk diketahui apakah konsep keadilan dan prinsip keadilan yang "fair" sudah terdapat di dalamnya.

Produk hukum yang mendasari berdirinya dan pelaksanaan KUR atau produk hukum yang berhubungan dengan berdirinya KUR antara lain:

1. UU No. 9 Tahun 1995 tentang Usaha Kecil

2. UU No. 20 Tahun 2008 tentang Usaha Mikro Kecil dan Menengah

3. Inpres No. 6 Tahun 2007 tentang Kebijakan Percepatan Pengembangan Riil dan Usaha Mikro Kecil dan Menengah.

4. Keppres No. 14 Tahun 2015 tentang Komite Kebijakan Pembiayaan bagi Usaha Mikro, Kecil dan Menengah

5. Keppres No. 19 Tahun 2015 tentang Perubahan atas Keputusan Presiden No. 14 Tahun 2015 tentang Komite Kebijakan Pembiayaan bagi UMKM

6. KEPMENKOPEREKONOMIAN No. 170 Tahun 2015 tentang Bank Pelaksana Kredit Usaha Rakyat dan Perusahaan Penjamin Kredit Usaha Rakyat

7. Beberapa Keputusan Kementerian Koperasi dan Usaha Mikro Kecil dan Menengah 
Dari perangkat hukum di atas, istilah Kredit Usaha Rakyat (KUR) sebagai pendanaan terhadap Usaha Mikro Kecil dan Menengah (UMKM) muncul pada poin nomor 3 (tiga) yaitu Inpres No. 6 Tahun 2007 Kebijkakan Percepatan Pengembangan Riil dan Usaha Mikro Kecil dan Menengah. Pada 2 (dua) UU yang di atas tidak menyebutkan secara tertulis Kredit Usaha Rakyat, namun pada UU No. 20 Tahun 2008 beberapa dituliskan kriteria-kriteria pendanaan untuk UMKM. Tetapi perlu diketahui Inpres tentang Kredit Usaha Rakyat hadir setahun lebih dulu dibanding UU No. 20 Tahun 2008 tentang UMKM. Hal ini menjadi suatu catatan bahwa "pemecahan masalah hadir mendahului prinsipprinsipnya".

Penekanan pada perangkat-perangkat hukum di atas, bila diteliti dengan seksama memiliki prioritas pada hal-hal yang berhubungan dengan perhitungan finansial: bunga kredit, plafon pinjaman, syaratsyarat untuk mendapatkan pendanaan dan lain sebagainya. Misalnya, penurunan bunga kredit dari semulanya $22 \%$ menjadi $12 \%$ yang kemudian diturunkan lagi menjadi $9 \%$ dan yang terbaru (2018) menjadi $7 \%$ per tahun. Namun penekanan pada misalnya tindakan-tindakan affirmative action ${ }^{23}$ yang disebut Rawls sebagai suatu ketidaksamaan sosial dan ekonomi yang perlu diatur sedemikian rupa, sehingga ketidaksamaan kesempatan akibat adanya perbedaan kualitas kemampuan, kemauan, dan kebutuhan dapat dipandang sebagai suatu nilai yang adil dan ditangani dengan tepat. ${ }^{24}$ Bukti dari situasi tersebut dapat diketahui dari hasil pelaksanaannya di lapangan seperti pendapat dari Ketua Asosiasi UMKM Indonesia (Akumindo) Ikhsan Ingratubun yang mengatakan, program KUR berbasis ekspor (KURBE) belum menunjukkan pengaruh signifikan terhadap pertumbuhan pelaku UMKM yang sudah mengekspor produk-produknya. Akumindo

\footnotetext{
23 Istilah yang sering dilekatkan pada Theory of Justice Rawls, bagaimana diberikan perlakuan berbeda untuk orang yang berbeda. Hal ini sesuai prinsip keadilan Rawls difference principle.

24 John Rawls, A Theory of Justice (Revised), 52-3.
} 
mempertanyakan ketepatan penyaluran pinjaman berbiaya murah tersebut karena sempat ada laporan bahwa dana itu justru lebih banyak didistribusikan kepada pemain besar. Padahal, menurut Ikhsan, minat pelaku UMKM untuk memanfaatkan KURBE cukup tinggi. ${ }^{25}$

\section{Prinsip-prinsip Keadilan Rawls Untuk Mendasari Peraturan yang Berkeadilan}

Teori Keadilan John Rawls ini masih populer hingga saat ini. Dengan dasar itulah Teori Keadilan John Rawls layak untuk mendasari evaluasi terhadap kebijakan KUR yang menjadi kebijakan ekonomi pemerintah Indonesia.

\section{Konsep dan Prinsip Keadilan Rawls}

Dalam karya fenomenalnya Theory of Justice, yang masih relevan sampai saat ini, John Rawls mencoba untuk menganalisis kembali permasalahan mendasar dari kajian filsafat politik dengan merekonsiliasikan antara prinsip kebebasan dan prinsip persamaan. Rawls mengakui bahwa karya tersebut sejalan dengan tradisi kontrak sosial (social contract) ${ }^{26}$ yang pada awalnya diusung oleh pelbagai pemikir kenamaan, seperti Thomas Hobbes, John Locke dan Jean Jacques Rousseau. ${ }^{27}$

Namun demikian, gagasan sosial kontrak yang dibawa Rawls sedikit berbeda dengan para pendahulunya, bahkan cenderung untuk merevitalisasi kembali teori-teori kontrak klasik yang bersifat utilitarianistik dan institusionistik. Dalam hal ini, kaum utilitaris mengusung konsep keadilan sebagai suatu keadaan di mana masyarakat dapat memperoleh kebaikan dan kebahagiaan secara sama rata. Rawls

\footnotetext{
25 http://semarang.bisnis.com/read/20160907/14/89288/kur-berbasis-ekspor-belumsignifikan-mendorong-ukm. Diakses 23 April 2017 dan 16 April 2018.

26 Magnis Suseno, Etika Politik: Prinsip Moral Dasar Kenegaraan Modern (Jakarta: Kompas Gramedia, 2016, cetakan kedelapan), 305-6.

27 John Rawls, A Theory of Justice (Revised), 10-5.
} 
berpendapat bahwa keadilan adalah kebajikan utama dari hadirnya institusi-institusi sosial (social institutions). ${ }^{28}$ Akan tetapi, menurutnya, kebaikan bagi seluruh masyarakat tidak dapat mengesampingkan atau mengganggu rasa keadilan dari setiap orang yang telah memperoleh rasa keadilan, khususnya masyarakat lemah. ${ }^{29}$ Oleh karena itu, sebagian kalangan menilai cara pandanga Rawls sebagai perspektif "liberalegalitarian of social justice".

Secara spesifik, Rawls mengembangkan gagasan mengenai prinsip-prinsip keadilan dengan menggunakan sepenuhnya konsep ciptaannya yang dikenal dengan "posisi asali" (original position) dan suatu istilah (veil of ignorance) "selubung ketidaktahuan"

Rawls meyakini keadilan yang "fair" hanya dapat dibicarakan apabila setiap orang mampu melepaskan diri dari predikat atau label sosial yang dimiliknya atau suatu ha-hal yang berhubungan dengan identias ras dan lain-lain. Rawls mengatakan keadilan yang dibicarakan dengan kesadaran akan label-label melekat pada individu akan menjadikan individu tersebut memilih keadilan yang condong atau mendukung kepada kepentingannya saat itu, misalnya, keadilan bagi seorang yang kaya adalah bagaimana dapat mengembangkan kekayaan dan bisa menikmatinya. Sebaliknya bagi seorang miskin keadilan adalah bagaimana distribusi kekayaan menjadi prioritas pemerintah. Sehingga suatu keadilan akan mencapai suatu pencapaian yang terbaik (yang disebut Rawls sebagai "justice as fairness") bila dibicarakan dalam suatu situasi dimana hanya kemampuan nalar dan pengetahuan yang dimiliki para pembicaranya tanpa disertai hal-hal lain seperti kedudukan sosial, tingkat kecerdasan dan lain sebainya. Posisi itu, di mana terjadi situasi yang sama dan setara itu disebut Rawls sebagai "posisi asali", sedangkan selubung ketidaktahuan adalah semacam selubung yang seperti me-

28 Pan Mohamad Faiz, "Teori Keadilan Rawls", Jurnal Konstitusi Vol. 6 (2009): 139.

29 John Rawls, A Theory of Justice (Revised), 19-25. 
nonaktifkan label-label sosial seseorang. ${ }^{30}$

Kondisi original position yang disebut Rawls itu secara rinci dan singkat dapat dituliskan: "posisi asali" yang bertumpu pada pengertian ekulibirum reflektif dengan didasari oleh ciri dengan didasari oleh ciri rasionalitas (rationality), kebebasan (freedom), dan persamaan (equality) guna mengatur struktur dasar masyarakat (basic structure of society).

Rawls menjelaskan para pihak di dalam posisi asali masingmasing akan mengadopsi terlebih dahulu dua pengandaian tipis sebelum para individu tersebut membicarakan keadilan. Hal ini menjadi penegas, bahwa arti paling dasar keadilan Rawls harus netral, artinya tidak boleh mengandaikan pandangan-pandangan filosofis dan ideologis tertentu. Dua pengandaian "tipis" itu adalah sesuatu yang dianggapnya tidak bisa dibantah, pertama, bahwa setiap orang ingin menjamin kepentingannya sendiri; kedua, bahwa manusia bersifat rasional dalam arti bahwa ia mampu bertindak tidak semata-mata secara emosional, melainkan berdasarkan kepentingan-kepentingannya sendiri. ${ }^{31}$

Berdasarkan dua pengandaian itu menurutnya, Rawls berpendapat bahwa setiap orang akan menyetujui dua prinsip berikut: Bahwa pertama, setiap orang berhak atas kebebasan yang sebesarbesarnya (equal liberty principle), tetapi kedua dengan pembatasan sedemikian rupa hingga suatu ketidaksamaan sosial dan ekonomis hanya dibiarkan berlangsung sejauh (a) menguntungkan, mendatangkan manfaat sebesar-besarnya bagi anggota masyarakat yang paling tidak diuntungkan (difference principle - maximin principle), dan (b) jabatanjabatan dan posisi-posisi harus dibuka bagi semua orang dalam keadaan di mana adanya persamaan kesempatan yang adil (equal opportunity principle). Dengan kata lain, perbedaan dalam kekayaan dan akses ke posisi-posisi berpengaruh hanya dapat dibenarkan bila mereka yang paling miskin dan lemah dalam masyarakat mendapatkan untung dari

\footnotetext{
30 John Rawls, A Theory of Justice (Revised), 144.

31 Magnis Suseno, Pijar-pijar Filsafat, 2006.
} 
ketidaksamaan itu. Paham Keadilan ini "prosedural" karena merupakan hasil sebuah "cara bertindak" bersama yang "fair" dan "material" karena menghasilkan dua prinsip yang selanjutnya menjadi tolok ukur keadilan dalam masyarakat.

Prinsip pertama tersebut dikenal dengan "prinsip kebebasan yang sama" (equal liberty principle), seperti misalnya kemerdekaan berpolitik (political of liberty), kebebasan berpendapat dan mengemukakan ekspresi (freedom of speech and expression), serta kebebasan beragama (freedom of religion). Sedangkan prinsip kedua bagian (a) disebut dengan "prinsip perbedaan" (difference principle) dan pada bagian (b) dinamakan dengan "prinsip persamaan kesempatan" (equal opportunity principle).

"Prinsip perbedaan" pada bagian (a) berangkat dari prinsip ketidaksamaan yang dapat dibenarkan melalui kebijaksanaan terkontrol sepanjang menguntungkan kelompok masyarakat yang lemah. Sementara itu prinsip persamaan kesempatan yang terkandung pada bagian (b) tidak hanya memerlukan adanya prinsip kualitas kemampuan semata, namun juga adanya dasar kemauan dan kebutuhan dari kualitas tersebut. Sehingga dengan kata lain, ketidaksamaan kesempatan akibat adanya perbedaan kualitas kemampuan, kemauan, dan kebutuhan dapat dipandang sebagai suatu nilai yang adil berdasarkan perspektif Rawls. Selain itu, prinsip pertama memerlukan persamaan atas hak dan kewajiban dasar, sementara pada prinsip kedua berpijak dari hadirnya kondisi ketimpangan sosial dan ekonomi yang kemudian dalam mencapai nilai-nilai keadilan dapat diperkenankan jika memberikan manfaat bagi setiap orang, khususnya terhadap kelompok masyarakat yang kurang beruntung (the least advantage).

Dalam kaitannya dengan prinsip-prinsip tersebut, Rawls meneguhkan adanya aturan prioritas ketika antara prinsip satu dengan lainnya saling berhadapan. Jika terdapat konflik di antara prinsip-prinsip tersebut, prinsip pertama haruslah ditempatkan di atas prinsip kedua, sedangkan prinsip kedua (b) harus diutamakan dari prinsip kedua (a). Dengan bahasa yang berbeda dapat dikatakan, prinsip-prinsip keadilan, 
harus diletakkan dalam sebuah tatanan leksikal; prinsip keadilan (2) baru boleh dilaksanakan apabila prinsip keadilan (1) sudah terwujud. Demikian juga prinsip keadilan ( $2 b)$ baru boleh dilaksanakan apabila prinsip keadilan (2a) sudah terpenuhi. Pengaturan seperti itu penting karena masing-masing prinsip memuat hak-hak dasar yang tidak bisa dipertukarkan.

Dengan demikian, untuk mewujudkan masyarakat yang adil, Rawls berusaha untuk memposisikan kebebasan akan hak-hak dasar sebagai nilai yang tertinggi dan kemudian harus diikuti dengan adanya jaminan kesempatan yang sama bagi setiap orang untuk menduduki jabatan atau posisi tertentu. Pada akhirnya, Rawls juga mengakui bahwa adanya pembedaan tertentu juga dapat diterima sepanjang meningkatkan atau membawa manfaat terbesar bagi orang-orang yang paling tidak beruntung. Dalam bahasa yang sedikit paradoks, John Rawls ingin berkata, bila ingin bersikap adil maka harus bersikap tidak adil, pemberlakuan satu jenis treatement untuk hal yang berbeda justru adalah ketidakadilan, hal yang berbeda harus dilakukan dengan treatment yang berbeda juga.

\section{Pareto Optimality dan Keadilan Distributif}

Perspektif Keadilan Rawls pada ujungnya adalah suatu keadilan yang berbasis kontribusi masing-masing aktor terhadap proses pasar. Hal ini dapat dipahami dengan memperhatikan prinsip keadilan kedua Rawls (equal opportunity principle).32 Prinsip umum keadilan Rawls yang disebut sebagai pareto optimality ${ }^{33}$. Dengan demikian dalam situasi praxis akan berlaku keadilan distributif. Maka masing-masing aktor akan mendapatkan sesuai dengan kontribusinya masing-masing.

Pada situasi tertentu kondisi pareto optimality dan keadilan

\footnotetext{
32 John Rawls, A Theory of Justice (Revised), 230-4.

33 Pareto optimal didefinisikan sebagai sebuah kondisi di mana sudah tidak mungkin lagi mengubah alokasi sumber daya untuk meningkatkan kesejahteraan pelaku ekonomi (better off) tanpa mengorbankan pelaku ekonomi yang lain (worse off).
} 
distributif ini dapat mendatangkan suatu masalah baru dalam masyarakat. Peran negara akan menjadi minimal pada situasi ini sebab negara hanya dapat hadir sebagai "juri" dengan membiarkan para aktor saling bertarung, sehingga kapitalis dan oligopolis-lah yang akan meraup supernormal profit sementara "masyarakat-masyarakat minus" yang di awal sudah mendapatkan "affirmative action" itu akan stagnan.

Dengan demikian, Egalitarion Justice yang menjadi spriti dari keadilan Rawls-pemberian perhatian pada khusus pada orang-orang minus (remedial action), perlu ditopang (sustain) atau diberikan suatu stopper kepada mereka, supaya dalam "pertarungan" di pasar, mereka tidak hancur akibat arus para kapitalis.

Pelaksanaan Pendanaan UMKM Melalui KUR Sebagai Sesuatu yang Berkeadilan dalam Prinsip Keadilan Rawls dan Relevansi Konstitusi

Prinsip-prinsip keadilan yang disampaikan oleh John Rawls pada umumnya sangat relevan bagi negara-negara dunia yang sedang berkembang, seperti Indonesia, misalnya. Relevansi tersebut semakin kuat tatkala hampir sebagian besar populasi dunia yang menetap di Indonesia masih tergolong sebagai masyarakat kaum lemah yang hidup di bawah garis kemiskinan. ${ }^{34}$

Akan tetapi, apabila dicermati jauh sebelum terbitnya karya-karya Rawls mengenai "keadilan sosial" (social justice), bangsa Indonesia sebenarnya telah menancapkan dasar kehidupan berbangsa dan bernegaranya atas dasar keadilan sosial. Dua kali istilah "keadilan sosial" disebutkan di dalam alinea keempat Pembukaan UUD 1945. Dengan demikian, keadilan sosial telah diletakkan menjadi salah satu landasan dasar dari tujuan dan cita negara (staatsidee) sekaligus sebagai dasar filosofis bernegara (filosofische grondslag) yang termaktub pada sila kelima

34 Pan Mohamad Faiz, "Teori Keadilan Rawls", Jurnal Konstitusi Vol. 6 (2009). 
dari Pancasila. Artinya, memang sejak awal the founding fathers mendirikan Indonesia atas pijakan untuk mewujudkan keadilan sosial baik untuk warga negaranya sendiri maupun masyarakat dunia. ${ }^{35}$ Dalam konsepsi Rawls, keadilan sosial tersebut dapat ditegakkan melalui koreksi terhadap pencapaian keadilan dengan cara memperbaiki struktur dasar dari institusi-institusi sosial yang utama, seperti misalnya pengadilan, pasar, dan konstitusi negara.

Apabila kita sejajarkan antara prinsip keadilan Rawls dan konstitusi, maka dua prinsip keadilan yang menjadi premis utama dari teori Rawls juga tertera dalam konstitusi Indonesia, terlebih lagi setelah adanya perubahan UUD 1945 melalui empat tahapan dari tahun 1999 sampai tahun 2002. Prinsip kebebasan yang sama (equal liberty principle) tercermin dari adanya ketentuan mengenai hak dan kebebasan warga negara (constitutional rights and freedoms of citizens) yang dimuat di dalam Bab X A tentang Hak Asasi Manusia, di antaranya yaitu Pasal 28E UUD 1945 mengenai kebebasan memeluk agama (freedom of religion), kebebasan menyatakan pikiran sesuai hati nurani (freedom of conscience), serta kebebasan berserikat dan mengeluarkan pendapat (freedom of assembly and speech). ${ }^{36}$

Begitu pula dengan prinsip kedua bagian pertama sebagai prinsip perbedaan (difference principle), Konstitusi Indonesia mengadopsi prinsip yang sama pada Pasal 28H ayat (2) UUD 1945 yang berbunyi, "Setiap orang berhak mendapat kemudahan dan perlakuan khusus untuk memperoleh kesempatan dan manfaat yang sama guna mencapai persamaan dan keadilan". Dari sinilah dasar penerapan affirmative action atau positive discrimination dapat dibenarkan secara konstitusional. ${ }^{37}$

\footnotetext{
Ibid.

Ibid.

37 Pan Mohamad Faiz, Teori Keadilan Rawls, Jurnal Konstitusi Vol. 6 (2009).
} 


\section{Pendanaan UMKM Melalui KUR}

Intervensi pemerintah melalui kebijakan pemberian pendanaan melalui program KUR--yang dimulai pada 2007-untuk UMKM adalah sesuatu yang diperlukan dalam penyelenggaran negara. Hal tersebut dapat dipandang sebagai suatu affirmative action seperti dalam perspektif Rawls. Secara khusus dalam upaya untuk menciptakan keadilan sosial atau kesejahteraan sosial hal ini pun sesuai dengan amanat UUD $1945^{38}$ Pasal 28H ayat (2) yang berbunyi, "Setiap orang berhak mendapat kemudahan dan perlakuan khusus untuk memperoleh kesempatan dan manfaat yang sama guna mencapai persamaan dan keadilan".

Dalam suatu masyarakat ekonomi yang liberal tentu intervensi seperti ini dapat dipandang sebagai pemborosan, sebab dalam perhitungan bisnis memberikan investasi seperti (KUR) pada sesuatu yang kapabilitasnya belum teruji atau terbukti adalah suatu risiko yang sangat buruk, suatu investasi yang buruk. Hal ini berbeda dengan pandangan Sistem Ekonomi Liberal -secara spesifik sistem liberal murni- yang menolak intervensi negara dalam ruang ekonomi dan kultural. Sistem tersebut mengharapkan campur tangan pemerintah tidak menyentuh konten sesuatu tindakan melainkan hanya membatasi diri sebagai penyedia ruang dan secara khusus pada pemeliharaan ketertiban dan keamanan. ${ }^{39}$ Meskipun sejarah telah membuktikan bagaimana sistem liberal murni hanya menciptakan suatu gap yang sangat tajam antara pemilik modal dan masyarakat pekerja, gini ratio yang sangat jauh dalam masyarakat di mana ada sekelompok masyarakat yang sangat kaya tetapi banyak kelompok masyarakat yang melarat dan miskin sampai kurang makan tentu hal itu adalah pelajaran berharga dalam sejarah bagaimana peran dan kehadiran negara sangat diperlukan

\footnotetext{
38 Dalam Pembukaan UUD 1945 telah dituliskan tujuan bernegara secara sangat luas, yakni (1) melindungi segenap bangsa dan seluruh tumpah darah Indonesia; (2) memajukan kesejahteraan umum; (3) mencerdaskan kehidupan bangsa; dan (4) ikut serta melaksanakan perdamaian dunia berdasarkan kemerdekaan.

39. Franz Magnis-Suseno, Etika Politik: Prinsip Moral Dasar Kenegaraan Modern, 408-9.
} 
dalam ruang-ruang kehidupan masyarakat termasuk ekonomi, agar terwujud situasi masyarakat yang sejahtera dan seadil mungkin dengan berbagai jenis sarana perwujudannya. ${ }^{40} \mathrm{Hal}$ tersebut diwujudkan tentu tanpa mengabaikan prinsip subsidiaritas ${ }^{41}$. Pelaksanaan pendanaan UMKM melalui KUR sesuai tujuan utamanya yang tertulis pada Inpres No.6 Tahun 2007 tentang Kebijakan Perkembangan Sektor Riil dan $\mathrm{UMKM}^{42}$, dapat dipandang sebagai equal access terhadap sumber modal didalam perspektif Rawls.

Sejak program KUR untuk UMKM ini digulirkan tahun 2007 dan berkesinambungan terus sampai 2016, ini merupakan angin segar bagi masyarakat yang memiliki minat dan potensi menjalankan usaha, atau warga yang ingin mengembangakan usaha mikro - menengah dalam berbagai bidang tetapi tidak memiliki modal usaha atau wawasan yang cukup untuk menjalankan bisnisnya. Program pendanaan melalui KUR untuk UMKM ini diharapkan menjadi sarana negara untuk membantu atau menjangkau kelompok masyarakat ekonomi lemah, kurang pengalaman dalam usaha, dan kekurangan-kekurangan lain untuk mampu meningkatkan hidupnya dengan menjalankan usaha produktif. Tercatat sepanjang 2016 penyaluran KUR mencapai Rp 94,4 triliun dari target penyaluran sebesar Rp 100 triliun. Hal ini menunjukkan tingginya serapan terhadap KUR ini.

Namun demikian, tercatat pula penyaluran dana KUR tidak optimal dalam meningkatkan kehidupan masyarakat disebabkan, antara lain penyaluran yang belum tepat sasaran serta pendampingan atau advokasi bagi para penerima modal usaha untuk mampu menjalankan usahanya tersebut. Seperti tercatat bagaimana keluhan dari Ketua Asosiasi UMKM Indonesia (Akumindo) Ikhsan Ingratubun yang

\footnotetext{
$40 \quad$ Franz Magnis-Suseno, Etika Politik: Prinsip Moral Dasar Kenegaraan Modern, 416.

41 Franz Magnis-Suseno, Etika Politik: Prinsip Moral Dasar Kenegaraan Modern, 420.

42 Kalimat pembuka Inpres No. 6 Tahun 2007 tentang Kebijakan percepatan pengembangan sektor riil dan pemberdayaan usaha mikro, kecil dan menengah: "Dalam upaya untuk lebih mempercepat pengembangan sektor riil dan pemberdayaan usaha mikro, kecil, dan menengah guna meningkatkan pertumbuhan ekonomi nasional..."
} 
mengatakan, program Kredit Usaha Rakyat berbasis ekspor (KURBE) belum menunjukkan pengaruh signifikan terhadap pertumbuhan pelaku UMKM yang sudah mengekspor produk-produknya. Akumindo mempertanyakan ketepatan penyaluran pinjaman berbiaya murah tersebut karena sempat ada laporan bahwa dana itu justru lebih banyak didistribusikan kepada pemain besar. Padahal, menurut Ikhsan, minat pelaku UMKM untuk memanfaatkan KURBE cukup tinggi. ${ }^{43}$ Sedangkan terkait advokasi atau pendampingan terhadap penerima modal/dana usaha KUR dalam menjalankan usahanya tidak tercantum secara jelas atau tidak diatur secara jelas dan terpilah dalam peraturan-peraturan yang primer tentang KUR seperti dalam Inpres No 6 Tahun 2007 Kebijakan Percepatan Pengembangan Riil-dan-Usaha Mikro Kecil dan Menengah, atau Keppres No 14/2015 tentang Komite Kebijakan Pembiayaan bagi Usaha Mikro, Kecil, dan Menengah dan Keppres No 19/2015 Perubahan Atas Keputusan Presiden Nomor 14 Tahun 2015 tentang Komite Kebijakan Pembiyaan bagi Usaha Mikro, Kecil dan Menengah, maupun dalam Kepmenkoperekonomian No 170 Tahun 2015 tentang Bank Pelaksana Kredit Usaha Rakyat dan Perusahaan Penjamin Kredit Usaha Rakyat.

Memang, dalam UU No. 20 Tahun 2008 tentang UMKM diatur bagaimana (secara umum) pendampingan dari pihak-pihak yang berhubungan terhadap Usaha-Usaha Mikro, Kecil dan Menengah agar sustain dan produktif menjalankan usahanya, namun hal ini tidak secara langsung merinci kepada penerima program KUR, demikian juga, seyogianya diperlukan peraturan-peraturan pelakasanaan UU seperti Perpres atau Permen yang berisi hal-hal yang lebih teknis dalam mengatur.

Kendala akibat tidak hadirnya advokasi atau pendampingan terhadap penerima dana KUR dirasakan langsung oleh penulis yang

43 http://semarang.bisnis.com/read/20160907/14/89288/kur-berbasis-ekspor-belumsignifikan-mendorong-ukm. Diakses 23 April 2017 dan 16 April 2018 
menjalankan usaha perikanan dilahan milik keluarga, di mana terjadi kesulitan-kesulitan dalam mendapatkan bibit, memilih jenis bibit dan penanganan ketika ikan yang dalam pembesaran mengalami sakit. Dalam hal ini (penyaluran dana dan advokasi) belum sesuai dengan prinsip kedua Rawls yaitu difference principle suatu remedial action yang berangkat dari ketidaksamaan sehingga diperlukan kebijaksanaan terkontrol sehingga menguntungkan kelompok "masyarakat yang lemah" belum terasa.

Hal lain yang menjadi faktor signifikan penyebab tidak optimalnya penyaluran KUR adalah skema cicilan belum kontekstual dalam memilah karaktertistik jenis usaha peserta KUR. Sebagai contoh. Sektor pertanian/perikanan memiliki karakteristik usaha yang berbeda bila dibanding dengan sektor dagang, di mana usaha pertanian/perikanan membutuhkan waktu lebih panjang sampai bisa mendapat hasil panen, sementara sektor dagang memerlukan waktu yang jauh lebih singkat. Hal ini disebabkan proses yang dijalani pada sektor pertanian/perikanan lebih panjang. Misalnya saja, waktu yang diperlukan untuk pembesaran ikan sampai pada tahap siap panen memerlukan paling tidak 3 (tiga) sampai 4 (bulan). Sehingga diharapkan cicilan atau pembayaran kredit kepada pemberi dana (bank, koperasi, dsb.) dimulai setelah panen pertama, sebab bagaimana dapat membayar cicilan jika belum mencapai hasil produksi. Sampai saat ini skema pembayaran kredit ini belum mendapat kebijakan baru dari pemerintah. Di dalam perspektif Rawls, hal ini belum memenuhi prinsip difference principle.

\section{Penutup}

Akhirnya, menjadi catatan penting dalam pelaksanaan KUR -yang secara teori keadilan sudah menunjukkan suatu sikap kebijakan tepat bagi negara- bahwa equal access terhadap modal usaha (dalam istilah John Rawls dapat disebut Equal Liberty), tampaknya tidak cukup, sebab faktanya masyarakat yang memiliki semangat maupun memiliki lahan tidak serta merta mampu menjalankan usahanya dengan baik, atau 
masyarkat yang baru pertama mendapatkan modal usaha tidak cukup berpengalaman menjalankan usahanya. Tentu hal ini tidak serta-merta dikaitkan dengan moralitas, bukan kemalasan melainkan kurangnya wawasan dan pengetahuan menjadi tantangan para perintis usaha ini. Dibutuhkan remedial action dari pemerintah untuk hal ini, yang dalam konsep keadilan Rawls, diperlukan The Difference Principle dan Principle of Fair Equality of Opportunity suatu prinsip yang diterapkan dalam hal "kesempatan", yang diintegrasikan ke dalam tata kelembagaan yang terbuka untuk semua untuk mencapai "keadilan", dalam konteks KUR untuk UMKM institusi pemerintah (pusat atau pemda) memberikan kesempatan untuk para penerima dana usaha KUR mendapat pelatihan dan pendampingan dalam menjalankan usahanya tersebut.

Hal lain yang juga penting dalam pemberian modal usaha terhadap UMKM ini adalah need justice, suatu kebijakan yang berpihak demi menciptakan keadilan, atau dalam bahasa Rawls, bila ingin bersikap adil maka harus bersikap tidak adil, dalam konteks pemberian modal usaha untuk UMKM adalah, skema cicilan untuk kategori usaha dagang dengan usaha pertanian/perikanan yang membutuhkan proses lebih panjang (paling tidak 3-4 bulan untuk mencapai panen) untuk mencapai hasil, maka sewajarnyalah diberlakukan pembayaran cicilan kredit dimulai setelah panen pertama. Dengan demikian maka memudahkan para petani atau pengusaha tambak untuk fokus pada proses usahanya. Sehingga diharapkan para penerima modal usaha dapat bekerja maksimal dan menghasilkan pendapatan yang optimal selanjutnya berujung pada peningkatan ekonomi yang berarti pengurangan angka ketimpangan.

Pareto Optimality yang adalah suatu keniscayaan dalam Teori Keadilan Rawls ketika di tingkat praksisnya berlaku keadilan distributif di mana masing-masing aktor akan memperoleh sesuai dengan kontribusinya dalam pasar. Bila keadilan Rawls berhenti pada tahap itu maka akan terjebak pada situasi di mana kapitalis dan oligopolis-lah yang akan meraup profit yang supernormal karena dalam persaingan 
yang terbuka pihak yang lebih kuatlah yang jadi pemenang, dengan begitu akan kembali terjadi stagnan kepada "masyarakat - masyarakat lemah". Tetap menjadi keharusan bagi negara untuk menopang supaya tercipta keadilan yang disebut Rawls sebagai Justice as fairness, negara menjadi "wasit" sekaligus menjadi "hakim" untuk menghadirkan need justice terhadap orang-orang khusus yang memerlukan remedial action. Supaya keadilan dan kesempatan bagi setiap warga negara dalam mencapai cita-cita hidup yang lebih baik dapat terwujud. Dengan Demikian ada harapan kemiskinan yang structural atau masyarakat sebagai komoditas ekonomi para politisi dapat diatasi, demi kehidupan yang lebih baik. 